\title{
Actinomyces Lymphadenitis: Case Report
}

\section{Aktinomiçes Lenfadeniti: Olgu Sunumu}

\author{
Deniz ARIK
}

Department of Pathology, Karaman State Hospital, KARAMAN, TURKEY

\begin{abstract}
In this paper an unusual case of lymphadenopathy associated with Actinomyces infection is reported. In the literature, there are only two cases presented with histopathologic features. A forty-year-old male patient was admitted to the hospital with painless mass on the neck. Clinical examination revealed a firm mass on the right submandibular region. The patient had no malignancy history. A cystic mass radiologically compatible with abscess was detected adjacent to the submandibular gland. Sialadenitis and lymphadenitis were considered but the mass was refractory to the antibiotherapy. The mass and the right submandibular gland were excised. Histopathologic evaluation of the lymph node revealed characteristic sulfur granules of Actinomyces.
\end{abstract}

Key Words: Actinomyces, Lymph node

\section{ÖZ}

Burada Aktinomiçes enfeksiyonuna sekonder lenfadenopati olgusu sunulmaktadır. Literatürde daha önce sadece iki olgu histopatolojik özellikleriyle yayınlanmıştır. Boyunda kitle şikayeti olan 40 yaşındaki erkek hasta hastanemize başvurdu. Klinik olarak sağ submandibuler bölgede ağrısız kitle saptandı. Radyolojik olarak kitle, submandibuler gland ile ilişkili, apse ile uyumlu kistik lezyon olarak değerlendirilmişti. Kitle, sialadenitis ve lenfadenitise yönelik antibiyotik tedavisine dirençliydi. Kitle ve submandibuler gland birlikte eksize edildi ve histopatolojik incelemede karakteristik Aktinomiçes sülfür granülleri görüldü.

Anahtar Sözcükler: Aktinomiçes, Lenf nodu

\section{INTRODUCTION}

Actinomyces is a gram-positive anaerobe that is usually seen in the pelvic region as a complication of an intrauterine device (1). Actinomycosis rarely occurs in humans but rather frequently in animals. It may extend to the lymph nodes but primary involvement by direct extension is rare (2-4). To the best of our knowledge, there is only one report with two cases about the histological features of actinomyces lymphadenitis in the English literature (4). Clinically actinomyces-associated lympadenopathy may suggest malignancy and may cause unnecessary surgical intervention. The chance of providing treatment by antibiotics increases the importance of a proper diagnosis.

\section{CASE REPORT}

A 40 year-old man was admitted to the hospital with a cervical mass. The medical history was significant for smoking and poor dentition. Physical examination revealed a firm painless mass on the submandibular region. Radiologically, a cystic mass compatible with abscess was detected adjacent to the submandibular gland. Initially, sialadenitis and lymphadenitis were considered, but treatment by antibiotics

(Turk Patoloji Derg 2013, 29:80-82)

Received : 31.10.2010 Accepted : 23.02.2011 did not help. The right submandibular gland and cervical lymph nodes were excised.

Pathologic examination of the submandibular gland revealed no abnormalities. There were three lymph nodes measuring $2 \mathrm{~cm}$ in diameter. Microscopically, extensive fibrous thickening of the lymph node capsule (Figure 1), activated germinal centers and thick fibrous bands between the lymphoid folliculus were seen (Figure 2). There were microabscesses with characteristic sulfur granules of Actinomyces (Figure 3). These granules were positive with Gram and PAS stains, histochemically. Branched filaments at the periphery of the colonies (Figure 4) and numerous histiocytes scattered throughout the abscess with engulfed neutrophils (Figure 5) were detected.

\section{DISCUSSION}

Actinomyces occur as a commersal in the oral cavity and gastrointestinal tract of healthy persons. It rarely causes disease (5). Actinomycosis may affect the cervicofacial, mediastinal, abdominal or pelvic regions (1,6-10). The main step in the pathogenesis of actinomycosis is interruption of the mucocutaneus barriers leading to suppuration and

Correspondence: Deniz ARIK

Department of Pathology, Karaman State Hospital, KARAMAN, TURKEY

E-mail: denarik@hotmail.com Phone: +90 5052550823 


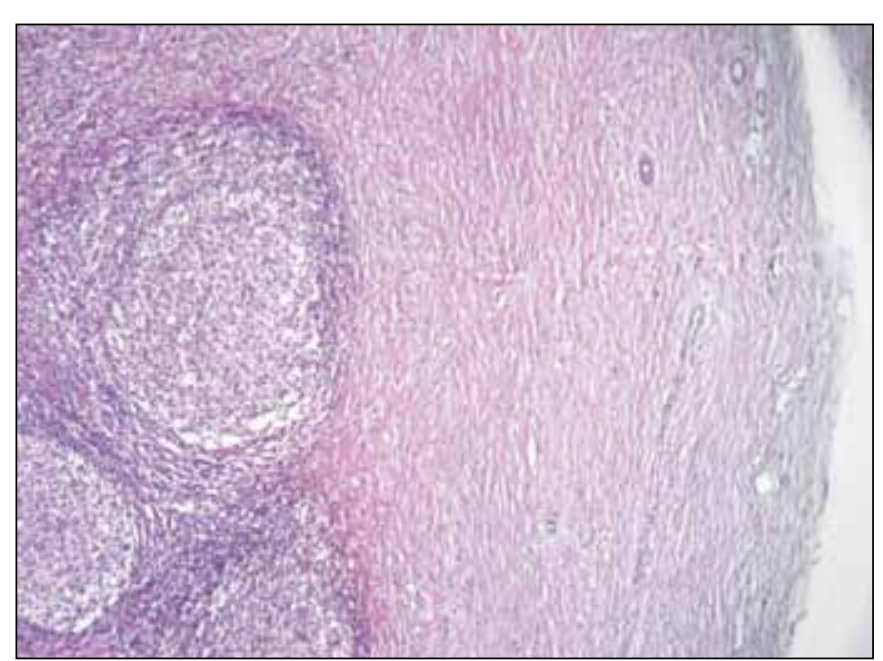

Figure 1: Thick fibrous capsule of the lymph node (H\&E, $\mathrm{x} 4)$.

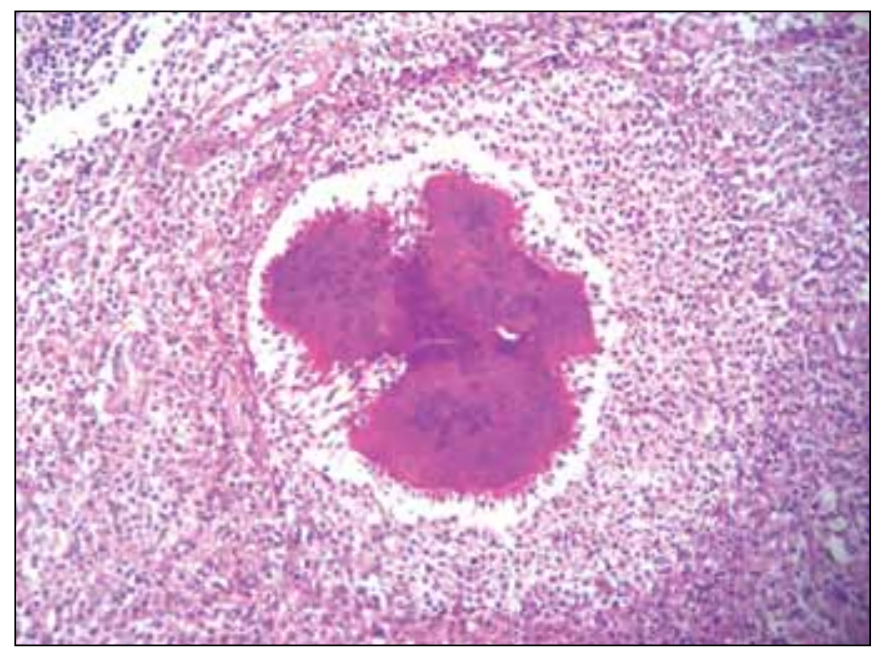

Figure 3: Characteristic sulfur granules of Actinomyces in the microabscess (H\&E, x10).

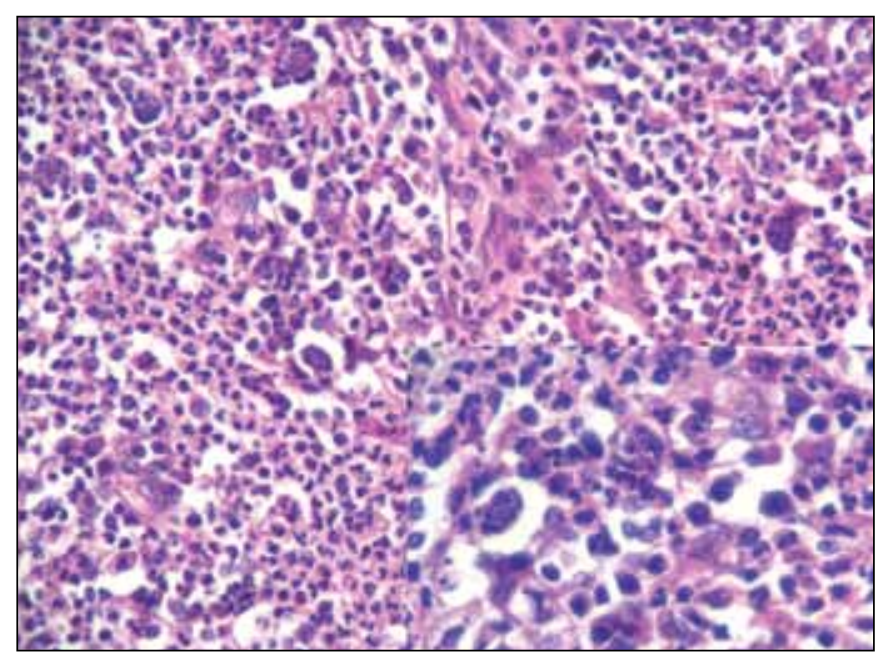

Figure 5: Scattered numerous histiocytes throughout the abscess (H\&E, x20), some of them with engulfed neutrophils (inset) (H\&E, $\mathrm{x} 40)$.

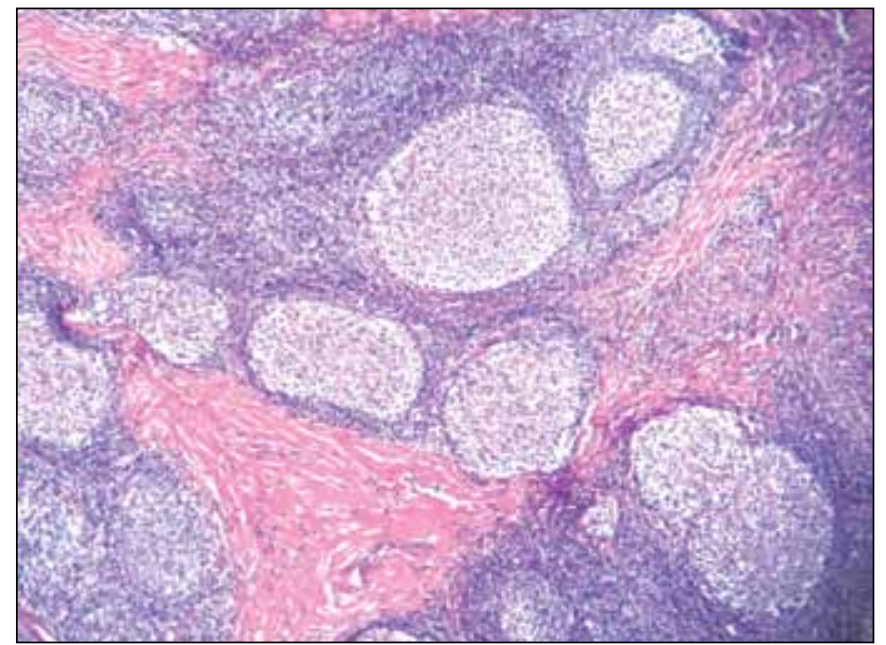

Figure 2: Fibrous bands between the lymphoid folliculus (H\&E, $\mathrm{x} 4)$.

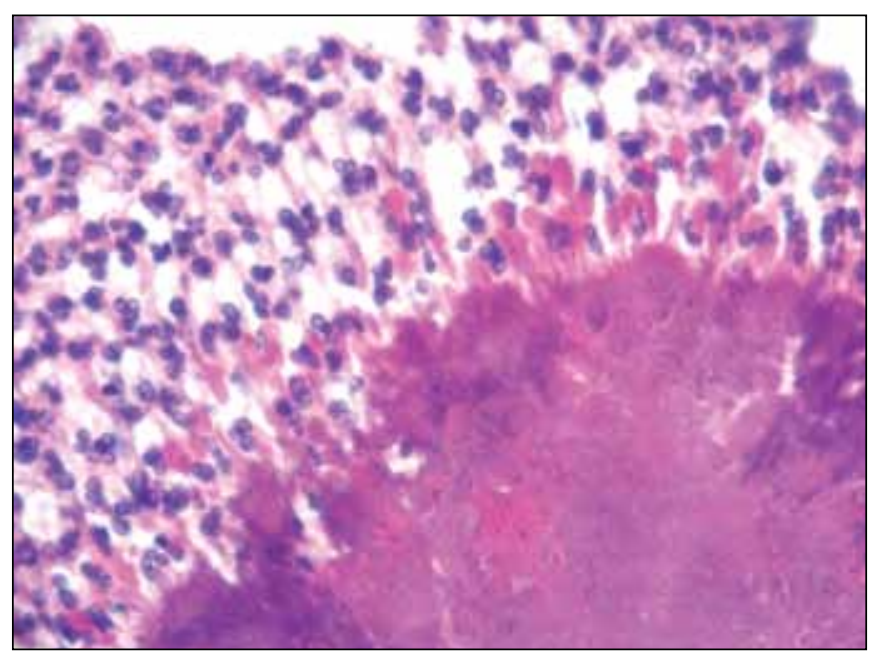

Figure 4: Filamentous branching of the bacteria at the periphery of the colonies (H\&E, $\mathrm{x} 40$ ).

abscess formation. The abscess then expands into adjacent tissue with no regard to tissue planes. The most common route of spread is local invasion. Although hematogenous dissemination can occur, particularly to the brain and lungs, lymphatic spread is uncommon.

Lymphadenopathy is a common clinical finding in many neoplastic and infectious diseases. Generally infectious lymphadenopathy reveals non-specific histologic features. Diagnostic morphologic findings can be detected in a few infectious conditions, such as cat-scratch disease, lymphogranuloma venereum, infectious mononucleosis, syphilis, and HIV infection (13). The histopathologic appearance of actinomycosis is similar in the various organs involved (4). These lesions have an outer zone of granulation tissue and a central abscess surrounding Actinomyces colonies $(1,4,11,12)$. In lymph nodes, histologic features suggestive of 
Actinomyces infection are fibrous thickening of the capsule, nodulation with fibrous bands, multiple abscesses with central loculation, and scattered neutrophil-laden macrophages. Characteristic sulfur granules may be seen in some sections $(2,4)$. In contrast to cat-scratch disease and lymphogranuloma venereum, palisading histiocytes are not noted around the microabscess. The prominent fibrosis of the lymph node capsule may mimic the fibrosis seen in syphilitic lymphadenitis but plasmacytic infiltration of the capsule is not prominent in Actinomyces lymphadenitis.

Amrikachi et al. reported two cases of Actinomycesinduced lymphadenitis in the submandibular region and mediastinum. One of the cases had concurrent infection with Actinomyces and Actinobacillus actinomycetemcomitans (4). Paik et al. reported a case of Actinomyces lympadenopathy on the neck diagnosed by fine needle aspiration cytology (FNA). The findings emphasized the potential value of FNA cytology. Smears from the enlarged lymph nodes with acute inflammatory exudate should be examined carefully for this organism (2). It should be kept in mind that in a lymph node, actinomycosis may be associated with hematologic malignancies (14).

Actinomycosis is usually treated successfully with long-term penicillin $G$ therapy. Effective antimicrobial treatment for actinomycosis requires the identification and susceptibility testing of any associated gram-negative infection (4). In our case, there was no material for microbiological examination.

In summary, actinomycosis-associated lymphadenopathy is a rare condition that may clinically simulate malignancy. Actinomyces infection should be included in the differential diagnosis in patients with poor dental hygiene. FNA cytology may be used for diagnosis in refractory lesions. Microbiologic examination also plays a crucial role in the definitive diagnosis. Appropriate diagnosis significantly affects the patient management. In histopathologic examination of lymph nodes, the presence of capsular thickening with reactive germinal centers, intranodal fibrosis, multiple microabscesses and scattered neutrophilladen macrophages suggests actinomycosis and multiple sections may be needed for identification of specific sulfur granules.

\section{ACKNOWLEDGMENTS}

I would like to thank Professor Mustafa Fuat Açıkalın, MD from Eskişehir Osmangazi University Department of Pathology for his suggestions.

\section{REFERENCES}

1. Boyle DP, McCluggage WG: Combined actinomycotic and pseudoactinomycotic radiate granules in the female genital tract: Description of a series of cases. J Clin Pathol 2009, 62: 1123-1126

2. Paik SS, Jang SJ, Park YW, Lee JD: Actinomycosis in a lymph node diagnosed by fine needle aspiration cytology. Acta Cytol 1998, 42: 828-829

3. Brown JR: Human actinomycosis. A study of 181 subjects. Hum Pathol 1973, 4: 319-330

4. Amrikachi M, Krishnan B, Finch CJ, Shahab I: Actinomyces and actinobacillus actinomycetemcomitans-Actinomyces-associated lymphadenopathy mimicking lymphoma. Arch Pathol Lab Med 2000, 124: 1502-1505

5. Akiyama T, Miyamoto H, Fukuda K, Sano N, Katagiri N, Shobuike T, Kukita A, Yamashita Y, Taniguchi H, Goto M: Development of a novel PCR method to comprehensively analyze salivary bacterial flora and its application to patients with odontogenic infections. Oral Surg Oral Med Oral Pathol Oral Radiol Endod 2010, 109: 669-676

6. Sakallıŏ̆lu U, Açıkgöz G, Kirtiloğlu T, Karagöz F: Rare lesions of the oral cavity: Case report of an actinomycotic lesion limited to the gingiva. J Oral Sci 2003, 45: 39-42

7. Alborzi A, Pasyar N, Nasiri J: Actinomycosis as a neglected diagnosis of mediastinal mass. Jpn J Infect Dis 2006, 59: 52-53

8. Cetinkaya Z, Kocakoc E, Coskun S, Ozercan IH: Primary hepatic actinomycosis. Med Princ Pract 2010, 19: 196-199

9. Latawiec-Mazurkiewicz I, Juszkiewicz P, Pacanowski J, Kwas A, Rybkiewicz M, Rudnicki J, Walecka A, Musiat S: Tumour-like inflammatory abdominal conditions in children. Eur J Pediatr Surg 2005, 15: 38-43

10. Nunoo-Mensah JW, Joglekar VM, Nasmyth GD, Partridge SM: Abdominal actinomycosis-can early diagnosis prevent extensive surgery? Int J Clin Pract 2010, 64: 106-109

11. Budenz CL, Tajudeen BA, Roehm PC: Actinomycosis of the Temporal Bone and Brain: Case report and review of the literature. Ann Otol Rhinol Laryngol 2010, 119: 313-318

12. Celebi S, Sevinir B, Saraydaroglu O, Gurpinar A, Hacimustafaoglu M: Pulmonary actinomycosis.Indian J Pediatr 2009, 76: 236-238

13. Rosai J: Lymph Nodes. In Rosai J. (Ed.): Rosai and Ackerman's Surgical Pathology. 9th ed., Philadelphia, Mosby, 2004:1878-1974

14. Dentale N, Fulgaro C, Fasulo G, Guerra L, Legnani G, Mazzetti M, Poletti V, Gritti FM: Cervicofacial and pulmonary actinomycosis associated with non-Hodgkin's lymphoma. Scand J Infect Dis 1998, 30: 519-520 